\title{
Adam Rutkiewicz
}

\section{Historia kieleckiego Zakładu Medycyny Sądowej ${ }^{1}$}

W maju 1969 roku Minister Zdrowia i Opieki Społecznej powołał przy Szpitalu Wojewódzkim w Kielcach Zespół Nauczania Klinicznego Akademii Medycznej w Krakowie. Była to (obok ośrodka rzeszowskiego) pierwsza tego rodzaju w Polsce, filialna, medyczna placówka dydaktyczno-naukowa, kształcąca w zakresie studiów lekarskich. W 1982 roku Minister Zdrowia przekształcił ww. Zespół w Katedrę Nauczania Klinicznego, a w 1986 roku w Instytut Medycyny Klinicznej ww. Akademii. Instytut zakończył działalność w 1991 roku.

W 1985 roku w ramach wspomnianej Katedry Nauczania Klinicznego został powołany do życia i rozpoczął działalność Zakład Medycyny Sądowej. Placówka została włączona do struktury Wojewódzkiego Szpitala Zespolonego w Kielcach i jej oficjalna nazwa brzmiała „Wojewódzki Szpital Zespolony Katedra Nauczania Klinicznego Zakład Medycyny Sądowej w Kielcach". Kierownikiem Zakładu został jego bezpośredni organizator, dr (dr hab./prof.) Franciszek M. Trela². Placówka uzyskała siedzibę w nowo wybudowanym i specjalnie na jej potrzeby zaprojektowanym, obszernym, dwukondygnacyjnym, wolnostojącym budynku przy ul. Związku Walki Młodych (obecnie Radiowa) 5. Została zorganizowana jako zespół pracowni: tanatologicznej, oznaczania alkoholu, serologicznej, mikroskopowej i fotograficznej. Dysponowała salą wykładową. Poza działalnością usługodawczą na rzecz organów ścigania przestępstw i wymiaru sprawiedliwości, w Zakładzie prowadzone były wykłady z medycyny sądowej i zajęcia prosektoryjne dla studentów medycyny (do 1991 roku) oraz aplikantów prokuratorskich i sądowych, szkolenia dla anatomopatologów powoływanych w tzw. terenie do sądowo-lekarskich oględzin i sekcji zwłok.

Asystentami Zakładu zostali: lek. med. Witold Kubeczko - patomorfolog, oficer z KWMO w Kielcach - w 1985 roku, autor publikacji - będący bezpośrednio po stażu podyplomowym - w 1986 roku. Poza prof. Trelą, ww. byli jedynymi w dziejach placówki, lekarzami zatrudnionymi w niej etatowo. Dr W. Kubeczko pracował w Zakładzie do 1988 roku zatrudniony na $1 / 2$ etatu. Autor publikacji pracuje w Zakładzie nieprzerwanie, na pełnym etacie. W 1995 roku powołany na p.o. kierownika, w 1999 roku mianowany jego kierownikiem.

Pracownia tanatologiczna, zlokalizowana w części parterowej budynku, składa się z szeregu pomieszczeń związanych funkcjonalnie, w tym: sali z szafą chłodniczą do przechowywania zwłok (sala ta służy też okazywaniu zwłok), sali sekcyjnej, magazynu materiału biologicznego, magazynu odzieży ze zwłok, śluzy z przebieralnią i łaźnią, pokoju socjalnego dla personelu prosektorium. Wzmiankowana szafa chłodnicza jest dziewięciostanowiskowa; trzy stanowiska mają możliwość mrożenia. Sala sekcyjna wyposażona jest w dwa stoły sekcyjne, wykonane z blachy nierdzewnej, wentylowane. Zarówno szafa jak i stoły to sprzęty firmy Hygeco, obecnie kilkuletnie. Sala sekcyjna posiada też automatycznie sterowaną, wysoko wydajną instalację nawiewu i wywiewu powietrza.

W pierwszych latach działalności Zakładu, oznaczanie alkoholu prowadzone było za pomocą metody Widmarka i enzymatycznej ADH. Zajmowała się tym bezpośrednio lek. weterynarii Bogumiła Chmielewska-Zielińska (wcześniej kierująca pracownią oznaczania alkoholu we krwi, funkcjonującą w kieleckim Wojewódzkim Szpitalu Zespolonym) przy współudziale technika chemika Aurelii Bartnik. W roku 1991 wprowadzono metodę chromatografii gazowej. Wówczas uruchomiony został chromatograf gazowy Chrom 5, pozyskany przez prof. Trelę z siostrzanego ZMS w Rzeszowie, od dr. Wiesława Gawrzewskiego (dr Gawrzewski został wyposażony w dwa takie urządzenia i jednym z nich, po koleżeńsku, podzielił się z prof. Trelą). Wdrożeniem

${ }^{1}$ Publikacja w ramach projektu „Ocalić od zapomnienia” realizowanego przez Komisję Historyczną Polskiego Towarzystwa Medycyny Sądowej i Kryminologii.

2 "Wspomnienie pośmiertne - Prof. dr hab. Franciszek Marian Trela 1934-2009” Archiwum Medycyny Sądowej i Kryminologii 2010.60.8-9.

${ }^{3}$ Patrz nota biograficzna s. 132 
nowej metody zajęła się mgr analityki medycznej Bożena Kwiatkowska, nowo przyjęta do pracy w zakładzie. Metodę Widmarka wykorzystywano jeszcze do 2003 roku, jako tanią metodę przesiewową. Dr B. Chmielewska-Zielińska przeszła na emeryturę w 1990 roku, a A. Bartnik przeszła na emeryturę w 2003 roku. W latach 1989-2001 w pracowni oznaczania alkoholu zatrudniona była również mgr ekonomii Maria Trela.

Obecnie pracownia alkoholowa posługuje się metodą enzymatyczną ADH oraz chromatografii gazowej, mając do dyspozycji chromatograf Trace GC Ultra firmy Thermo Scientific, wyposażony w dwie kolumny typu BAC1 i BAC2. Oznaczany jest alkohol etylowy, alkohol metylowy, alkohol izopropylowy i aceton. Dwiema metodami fotometrycznymi oznaczana jest też hemoglobina tlenkowęglowa. Ww. analizami zajmuje się mgr Kwiatkowska.

Badaniami śladów biologicznych w pracowni serologicznej, w latach 1985-1994, zajmowała się mgr biologii Lidia Stalmasińska. Gdy w 1994 roku odeszła z pracy (do kieleckiej Wojewódzkiej Stacji Krwiodawstwa) w ww. badaniach zastąpiła ją mgr B. Kwiatkowska. W pracowni przeprowadzane były badania grupowo-serologiczne krwi w zakresie układów ABO, Rh, Gm [cechy G1m(1) i G1m(2)], $\mathrm{PGM}_{1}$, Lewis (cechy a i b) i śliny w układzie $A B O$, badania śladów biologicznych - plam krwi i nasienia w zakresie przynależności gatunkowej i przynależności grupowej w układach ABO, Gm i PGM 1 . Z uwagi na rozwój badań DNA ślady biologiczne przestały być w Zakładzie badane i w 2002 roku pracownia przestała funkcjonować.

Pracownie mikroskopowa i fotograficzna funkcjonowały w ograniczonym zakresie. W pracowni mikroskopowej przygotowywane były i badane preparaty szkiełkowe do oceny na obecność zatorów tłuszczowych i nasienia ludzkiego, nadto badania morfologiczne włosów i identyfikujące ziarna prochu strzelniczego. O likwidacji ww. pracowni zadecydował rachunek ekonomiczny. Ta pierwsza działała do 2005 roku, a fotograficzna znacznie krócej.
Około 80\% zwłok przyjmowanych do Zakładu i tu badanych, kierowane jest z obszaru podległego Prokuraturze Rejonowej w Kielcach, a zatem z obszaru powiatu kieleckiego. Pozostałe $20 \%$ zwłok kierowane jest z innych niż kielecki powiatów województwa świętokrzyskiego. Rocznie w Zakładzie wykonuje się - średnio - ok. 280 badań sekcyjnych (ww. średnia została wyliczona z lat od 1986 do 2011). Np. w 2011 roku ww. badań przeprowadzono 228, a w 2010 roku 296. Oględzin zewnętrznych zwłok przeprowadza się rocznie średnio - ok. 20.

Prof. F. M. Trela pracował w Zakładzie od 1985 do 1999 roku; do 1995 roku na stanowisku kierownika, po czym w ramach $1 / 2$ etatu na stanowisku st. asystenta. Dr B. Chmielewska-Zielińska pracowała od 1985 do 1990 roku na stanowisku st. asystenta. Mgr L. Stalmasińska pracowała od 1985 do 1994 roku jako st. asystent. Mgr M. Trela pracowała od 1989 do 2001 roku jako mł. asystent. A. Bartnik pracowała od 1985 do 2003 roku jako st. technik analityk.

W Zakładzie pracowały też m.in.: Jolanta Gizińska - starszy technik analityki - w latach 19912001, Mieczysława Misztal - technik ekonomii w latach 1985-2002. Panie te zatrudnione były w pracowniach oznaczania alkoholu, serologicznej i mikroskopowej.

Obecnie w Zakładzie, etatowo zatrudnionych jest pięć osób: autor publikacji - na stanowisku kierownika Zakładu, mgr B. Kwiatkowska - w pracowni oznaczania alkoholu, mgr Edyta Kwaśniewska - prowadząca sekretariat, Krzysztof Łukasik i Grzegorz Skrzyniarz - pomocnicy sekcyjni.

Prezentowana publikacja bazuje prawie wyłącznie na dokumentacji własnej Zakładu. Nie zachowała się bowiem żadna merytoryczna dokumentacja w archiwach Wojewódzkiego Szpitala Zespolonego w Kielcach (poza aktami osobowymi pracowników Zakładu) ani też w Archiwum Urzędu Wojewódzkiego. Również w publikacji dr. J. Krzewickiego „Szkic z dziejów dydaktyki medycznej w Kielcach" brak informacji o Zakładzie. 


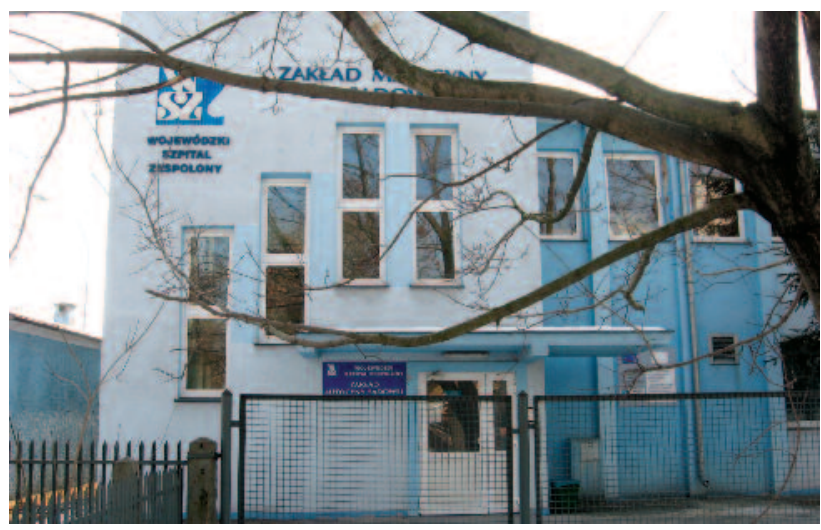

Ryc. 1. Zakład Medycyny Sądowej w Kielcach.

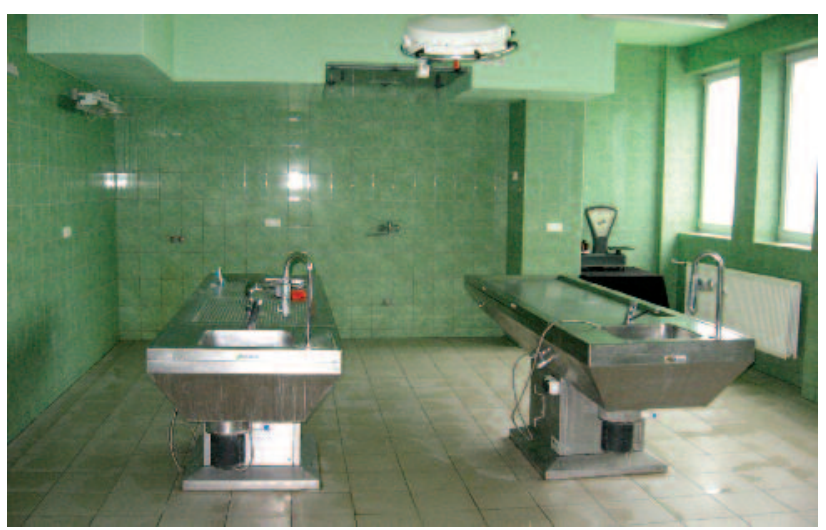

Ryc. 2. Sala sekcyjna.

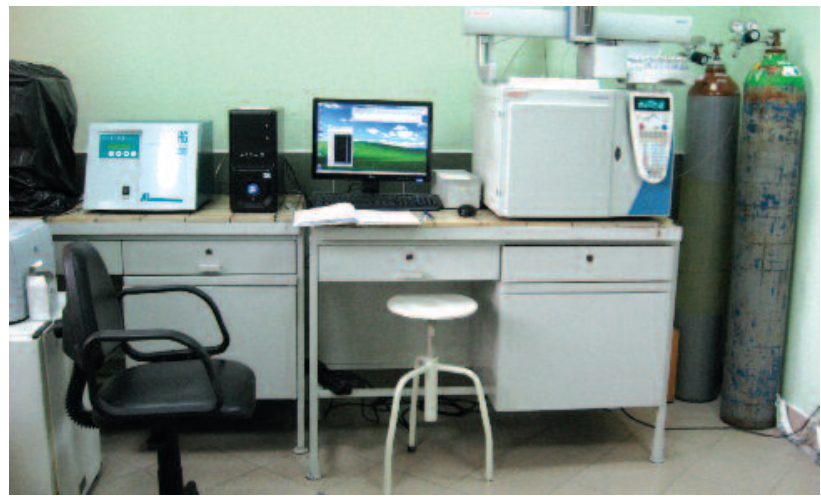

Ryc. 3. Pracownia.

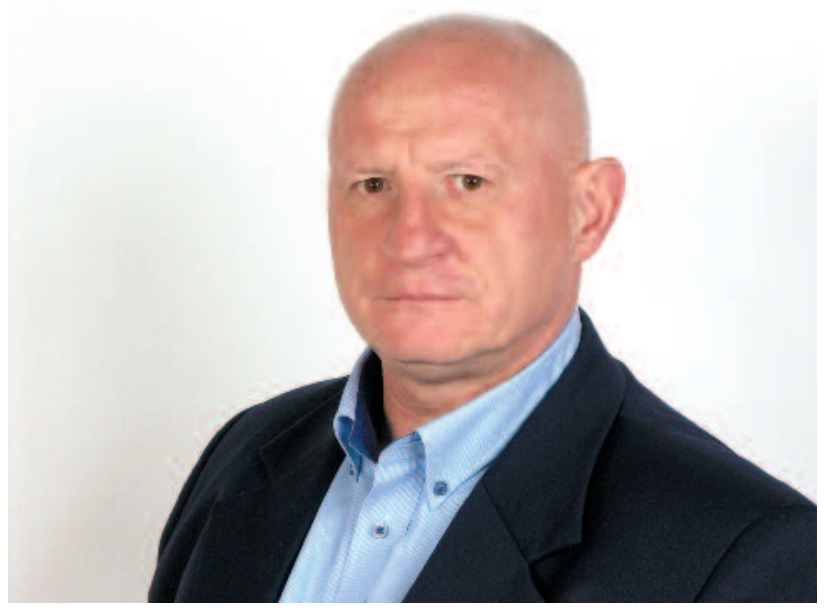

Nota biograficzna autora

Adam Rutkiewicz, rocznik 1958. Absolwent Wydziału Lekarskiego ŚIAM w Katowicach. Od roku

Od Redakcji: w czasie przygotowywania artykułu do druku otrzymaliśmy informację, że Zakład
1986 związany zawodowo z Zakładem Medycyny Sądowej w Kielcach, którym kieruje od 1999 roku. Specjalista medycyny sądowej II stopnia (specjalizował się stażując w macierzystym Zakładzie i w Katedrze Medycyny Sądowej w Krakowie, pod kierunkiem prof. F. M. Treli). Członek PTMSiK. Biegły sądowy z listy Prezesa Sądu Okręgowego w Kielcach. W latach 1999-2011 Konsultant Wojewódzki w dziedzinie medycyny sądowej dla województwa świętokrzyskiego. Żonaty - żona Mariola kardiolog dziecięcy. Dwie dorosłe córki.

Adres do korespondencji: dr Adam Rutkiewicz

ul. Sienkiewicza 28/28

25-301 Kielce

Medycyny Sądowej w Kielcach został rozwiązany z dniem 30 marca 2013 roku. 